\title{
A Study on Diametrical Compression Test of Inada Granite
}

\author{
by
}

Yuichi KoHMURA*

In this study, the diametrical compression test was carried out using Inada granite by attaching strain gages to the test specimen. Young's modulus under tensile stress was estimated from the value of the measurement of the strain. The results obtained through this study are as follows:

1) It is deemed that Young's modulus under tensile stress can be estimated from the diametrical compression test results by the method shown in this research.

2) The standard deviation of tensile strain was calculated. The results showed that standard deviation increases rapidly, once the tensile stress exceeds a certain value. It is considered that the stress of a tensile fracture area differs within a test specimen if the load increases. Therefore, if tensile strength estimates from $\mathrm{St}=-2 \mathrm{P} / \pi$ DL use maximum load, it is possible that tensile strength was overestimated.

Key words: Diametrical compression test, Rock, Tensile strength, Young's modulus, Anisotropy

\section{1 緒言}

岩石の引張強度を評価する試験方法の一つに圧裂試 験がある．岩石を対象とした研究としては，花崗岩の圧 裂引張強度のばらつきに関する研究 ${ }^{1)} や$, 圧裂引張強度 の載荷速度依存性を検討した研究2）が報告されている. 引張強度を評価する他の試験方法として，一軸引張試験 がある、筆者も花崗岩を対象とした一軸引張試験結果を 報告しているが ${ }^{3)}$ ，試験ごとに接着剤を用いて供試体を 加圧板と接着させ，接着剂が硬化するのを待ち試験を開 始するなど，一軸引張試験は多くの時間を必要とする. これに比較して，圧裂試験は短時間に簡易に試験を行う ことができる点で優れていると考えられる。一方で,一 軸引張試験では軸ひずみと荷重を計測することで, 引張 応力下におけるヤング率を計測できる. 花崗岩は圧縮応 力下と引張応力下ではヤング率が異なることが知られ ている ${ }^{4)}$.このため, 引張応力下におけるヤング率を計 測することは重要であると考えられるが，圧裂試験では 引張応力下におけるヤング率の測定法が確立されてお らず，圧裂引張強度の評価しかできない，また，試験は 供試体に線荷重を載荷する必要があるが，荷重が大きく なると供試体と加圧板との接触面近傍での局所的な破 壊が生じることが予測され, 線荷重という条件が満足さ れない可能性も考えられる。このため, 圧裂試験の試験 方法自体の妥当性にも疑問が残る。これまでに試験方法 そのものに着目した研究も報告されている5） ${ }^{5)}$.

このような背景のもとで, 本研究では稲田花崗岩を用 いて供試体にひずみゲージを貼り付けた状態で圧裂試 験を実施した。試験時に得られたひずみのデータから， まず, 引張応力下におけるヤング率を推定し, 過去に報
告している一軸引張試験で得られたヤング率と比較し て考察を行う。次に，ひずみの計測值から引張強度の評 価方法に関して考察した結果を述べる.

\section{$2 \cdot 1$ 試験に用いた供試体}

試験には茨城県笠間市産の通称稲田花崗岩を用いた。 今回使用した稲田花崗岩の鉱物粒子は石英，カリ長石お よび斜長石の 3 種で体積の約 $95 \%$ を占める. それぞれの 平均的な粒径はいずれも約 $3 \mathrm{~mm}$ である。本研究には粒 径の小さな岩石を使用することが望ましいと考えられ る. 鉱物粒子の平均的な粒径が後述するひずみゲージの 長さより小さいこと，かつ，これまでの研究 ${ }^{3) ， 9) ， 10) ~ と ~}$ の連続性を考慮して稲田花崗岩を使用することとした。 花崗岩にはマイクロクラックの配向性に起因するいわ ゆる石の目が存在することが知られている ${ }^{1)}$. サンプリ ングは $250 \mathrm{~mm}$ 角の立方体ブロックで行い，この際，ブ ロックの各面が現地で経験的に知られている Rift plane, Grain plane および Hardway plane ${ }^{1)}$ に一致するようにした。 圧裂試験用の供試体は直径 $35 \mathrm{~mm}$, 長さ $35 \mathrm{~mm}$ とし, Grain plane に垂直な方向に作製した。供試体作製後，3 か月 間室内で乾燥した後に試験に用いた。

\section{$2 \cdot 2$ 圧裂試験の方法}

供試体は圧裂引張面が Hardway plane に一致する方向 (以下H方向と呼ぶ）および Rift plane に一致する方向 （以下R方向と呼ぶ）になるように, 各 6 本の供試体で 試験を行った。試験にあたっては, Fig.1 に示すように供 試体前後の端面の中心に，2軸のひずみゲージを貼り付 け，圧裂引張面に垂直な方向（X方向）および平行な方 向（Y方向）のひずみを計測し，両端面のゲージの平均

$\dagger \quad$ 原稿受理 平成25年12月26日 Received Dec. 26, 2013 ○2014 The Society of Materials Science, Japan

* 正会員 (株)竹中工務店技術研究所 干270-1395 印西市大塚，Takenaka R\&D Inst, Ohtsuka, Inzai 270-1395 


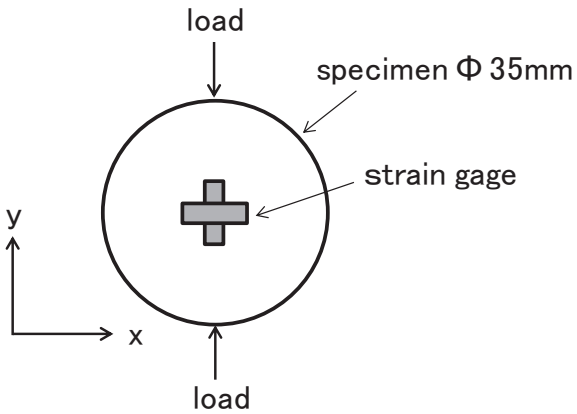

Fig.1 Schematic diagram of the specimen.

值をそれぞれ $\varepsilon_{\mathrm{x}}$ および $\varepsilon_{\mathrm{y}}$ とした。各ゲージの長さは $10 \mathrm{~mm}$ ，幅は $3 \mathrm{~mm}$ である.

試験は（1）式 ${ }^{11)}$ による圧裂引張面の応力（圧縮側 が正）が- $0.1 \mathrm{MPa} / \mathrm{s}$ の速度で増加するように制御した。

$$
\mathrm{S}_{\mathrm{t}}=-2 \mathrm{P} / \pi \mathrm{DL}
$$

ここで、 $\mathrm{S} \mathrm{t}$ は圧裂引張面の応力， $\mathrm{P}$ は荷重， D は供 試体の直径およびLは供試体の長さである。なお、荷重 およびひずみゲージのデータの測定間隔は $0.5 \mathrm{~s}$ とした。

\section{3 試験結果}

\section{$3 \cdot 1$ 供試体のひずみの計測結果}

$\mathrm{H}$ 方向およびR方向で各 6 回の試験を行って得られ た応力ーひずみ曲線を Fig.2 に示す. なお, 図の縦軸の 応力は, (1) 式によって求めた圧裂引張面の応力であ り，応力およびひずみともに圧縮側を正として示した. H方向およびR方向とも, 応力が小さい領域では供試体 間で $x_{\mathrm{x}}$ および ${ }_{\mathrm{Y}}$ ともに大きなばらつきは見られない ものの, 応力が大きくなり引張破壊に近づくにつれて応 カーひずみ曲線のばらつきが大きくなることがわかる。

\section{$3 \cdot 2$ 圧裂引張強度の計算結果}

破壊時の荷重から（1）式を用いて圧裂引張強度を求 めた結果を Table1 に示す. H方向とR方向とでは圧裂引 張強度に明らかな差がみられR方向で值が小さい。これ は, Hardway plane に比較して, Rift plane に多くのマイ クロクラックが含まれているため ${ }^{3)}$ と考えられる.

\section{4 考察}

\section{$4 \cdot 1$ ヤング率の推定}

ここでは, Fig.2で得られた応力ーひずみ曲線から引張 応力下における割線ヤング率を推定する. Fig. $3^{11)}$ に示す ように座標を定義した場合，供試体の任意の点Aにおけ る応力は (2) 〜 (4) 式で求めることができる ${ }^{11)}$. な お，圧縮側を正として示し，供試体の長さ方向は平面応 力状態とする.

$$
\begin{gathered}
\sigma_{\mathrm{x}}=\frac{2 \mathrm{P}}{\pi \mathrm{L}}\left(\frac{\sin ^{2} \theta_{1} \cos \theta_{1}}{\mathrm{r}_{1}}+\frac{\sin ^{2} \theta_{2} \cos \theta_{2}}{\mathrm{r}_{2}}\right)-\frac{2 \mathrm{P}}{\pi \mathrm{D} L} \\
\sigma_{\mathrm{y}}=\frac{2 \mathrm{P}}{\pi \mathrm{L}}\left(\frac{\cos ^{3} \theta_{1}}{\mathrm{r}_{1}}+\frac{\cos ^{3} \theta_{2}}{\mathrm{r}_{2}}\right)-\frac{2 \mathrm{P}}{\pi \mathrm{D} L} \\
\tau_{\mathrm{xy}}=\frac{2 \mathrm{P}}{\pi \mathrm{L}}\left(\frac{\cos ^{2} \theta_{1} \sin \theta_{1}}{\mathrm{r}_{1}}+\frac{\cos ^{2} \theta_{2} \sin \theta_{2}}{\mathrm{r}_{2}}\right)
\end{gathered}
$$

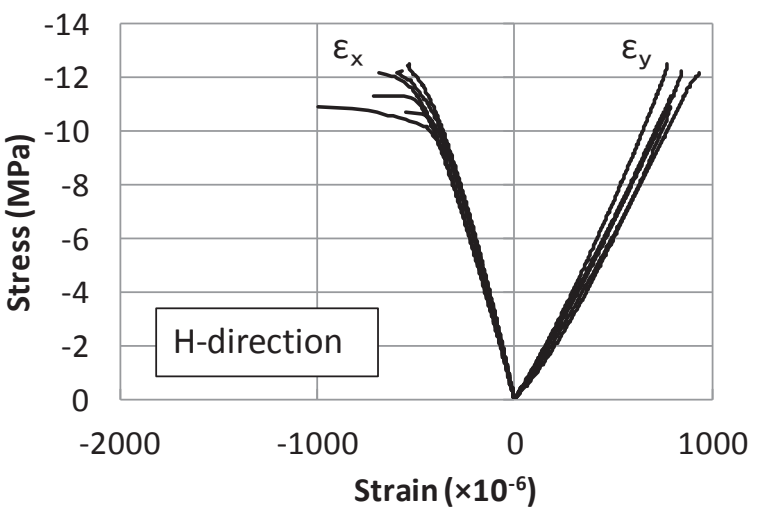

(a) H-direction

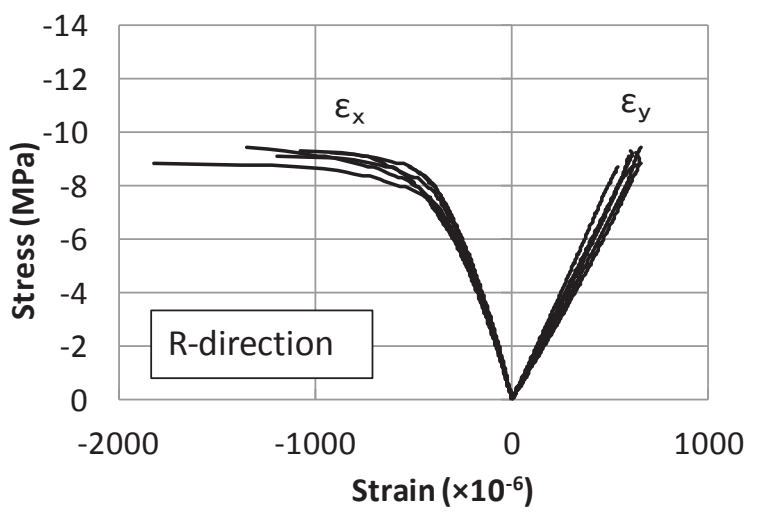

(b) R-direction

Fig.2 Stress strain curves obtained by the tests.

Table1 Result of diametrical compression tests.

\begin{tabular}{c|c|c}
\hline \multirow{2}{*}{ Specimen ID } & \multicolumn{2}{|c}{$\begin{array}{c}\text { Tensile strength obtained by } \\
\text { diametrical compression tests } \\
(\mathrm{MPa})\end{array}$} \\
\cline { 2 - 3 } & H-direction & R-direction \\
\hline 1 & -10.7 & -9.2 \\
\hline 2 & -12.2 & -9.3 \\
\hline 3 & -12.2 & -9.4 \\
\hline 4 & -10.9 & -8.7 \\
\hline 5 & -11.4 & -8.9 \\
\hline 6 & -12.4 & -9.1 \\
\hline Mean & -11.6 & -9.1 \\
\hline
\end{tabular}

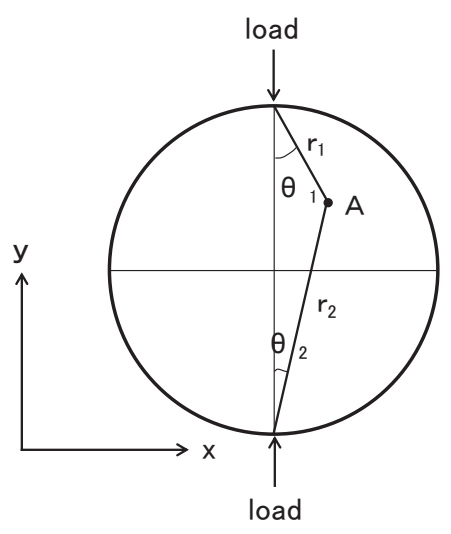

Fig. 3 Coordinates on a disk. ${ }^{11)}$ 


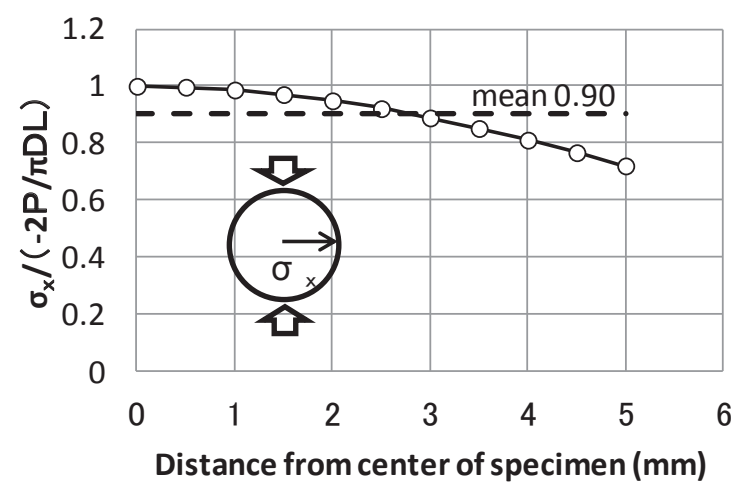

(a) Calculated value of $\sigma \mathrm{x}$

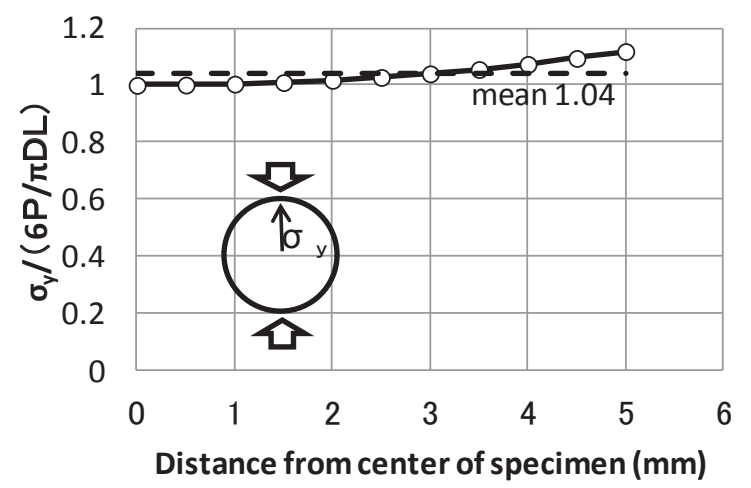

(b) Calculated value of $\sigma_{\mathrm{y}}$

Fig.4 The theoretical value of stress .

ここで，Pは荷重，Dは供試体の直径，Lは供試体の長 さである。なお，供試体中心では $\sigma_{\mathrm{x}}$ および $\sigma_{\mathrm{y}}$ は（5） 式および（6）で表される.

$$
\begin{gathered}
\sigma_{x}=-\frac{2 P}{\pi D L} \\
\sigma_{y}=\frac{6 P}{\pi D L}
\end{gathered}
$$

供試体中心ではx 方向に（5）式、y 方向に（6）式

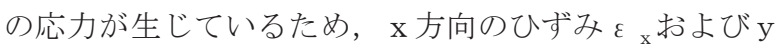
方向のひずみ $\varepsilon_{\mathrm{y}}$ は $(7$ ) 式および $(8)$ 式のようにな る.

$$
\begin{aligned}
& \varepsilon_{\mathrm{x}}=\varepsilon_{\mathrm{x}}{ }^{\prime}+v_{\mathrm{C}} \cdot \varepsilon_{\mathrm{y}}{ }^{\prime} \\
& \varepsilon_{\mathrm{y}}=\varepsilon_{\mathrm{y}}{ }^{\prime}+v_{\mathrm{T}} \cdot \varepsilon_{\mathrm{x}}
\end{aligned}
$$

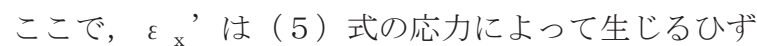
み, $\varepsilon_{\mathrm{y}}{ }^{\prime}$ は $(6)$ 式の応力によって生じるひずみ, $v_{\mathrm{C}}$ は圧縮応力下における割線ポアソン比, $v_{\mathrm{T}}$ は引張応力 下における割線ポアソン比である．稲田花崗岩の一軸引 張試験によって報告されている引張破壊時の割線ポア ソン比はH方向で 0.058 , R方向で 0.032 であり ${ }^{3)}$, 後述 する圧縮応力下における割線ポアソン比よりも小さい

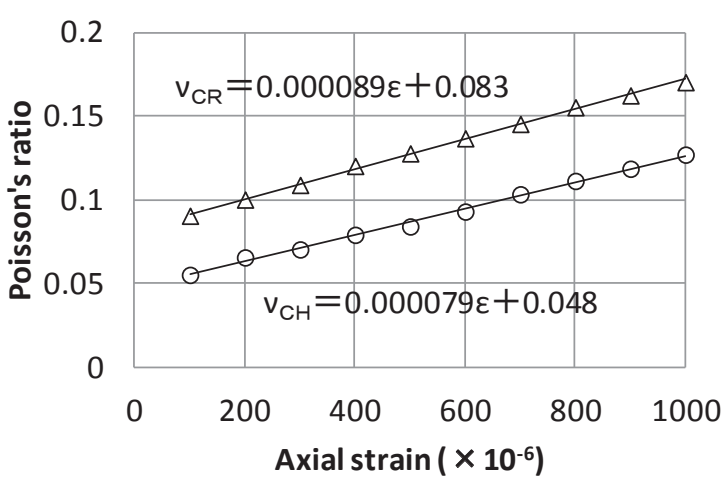

Fig.5 Poisson's ratio obtained by uniaxtial compression tests.

ため, $v_{\mathrm{T}} \fallingdotseq 0$ と仮定すると（8）式は（9）式となり，

（7）式を $\varepsilon_{\mathrm{x}}$ 'について整理すると（10）式となる.

$$
\begin{gathered}
\varepsilon_{\mathrm{y}}=\varepsilon_{\mathrm{y}} \\
\varepsilon_{\mathrm{x}}^{\prime}=\varepsilon_{\mathrm{x}}-v_{\mathrm{C}} \cdot \varepsilon_{\mathrm{y}}
\end{gathered}
$$

なお， $v_{\mathrm{T}}=0.05, \varepsilon_{\mathrm{X}}{ }^{\prime}=500 \times 10^{-6}, \varepsilon_{\mathrm{Y}}{ }^{\prime}=500 \times 10^{-6}$ と仮定して（8）式で $\varepsilon_{\mathrm{Y}}$ を求めた值は $525 \times 10^{-6},(9)$ 式で $\varepsilon_{\mathrm{Y}}$ を求めた值は $500 \times 10^{-6}$ である。 $v_{\mathrm{T}} \fallingdotseq 0$ と仮定 することによる（9）式での誤差は 5\%であり許容でき るものと考える.

よって, ひずみゲージの計測值 $\varepsilon_{\mathrm{x}}$ および $\varepsilon_{\mathrm{y}}$ から, 圧 裂引張面に生じる（5）式の応力によるひずみ $\mathrm{x}_{\mathrm{x}}$ ’を

（10）式によって求めることができ，（5）式の応力を このひずみで除すことにより引張応力下における割線 ヤング率を求めることができる.

なお, 本研究では, Fig.1に示したように供試体の中心 に長さ $10 \mathrm{~mm}$ の 2 軸のひずみゲージを貼り付けた. 供試 体中心から $\mathrm{x}$ 方向に（2）式を用いて $\sigma_{\mathrm{x}}$ の值を計算し たものを Fig.4(a)に、y方向に（3）式を用いて $\sigma_{\mathrm{y}}$ を計 算したものを Fig.4(b)に示す. Fig.4(a)から 0 x の值は供試 体中心から離れるに従って小さくなり，ひずみゲージの 端部では供試体中心の值の 0.7 倍程度にまで低下し, 供 試体中心から $5 \mathrm{~mm}$ の範囲の平均值は 0.90 である.また, Fig.4(b)から $\sigma_{\mathrm{y}}$ の值は供試体中心から離れるに従って大 きくなり, ひずみゲージの端部では中心の 1.1 倍程度に まで大きくなり, 供試体中心から $5 \mathrm{~mm}$ の範囲の平均值 は 1.04 である。 $\sigma_{\mathrm{x}}$ については供試体中心の值とひずみ ゲージの測定範囲の平均值との差が比較的大きいため, ひずみもこの割合で変化すると考え，(10）式を（11） 式のように補正した.

$$
\varepsilon_{\mathrm{x}}^{\prime}=\varepsilon_{\mathrm{x}} / 0.90-\nu_{\mathrm{C}} \cdot \varepsilon_{\mathrm{y}}
$$

また，(11）式には圧縮応力下における割線ポアソン 比 $v_{\mathrm{c}}$ が含まれている. 筆者は, 稲田花崗岩の一軸圧縮 試験の結果を報告している ${ }^{9), 10)}$. Hardway plane に平行 


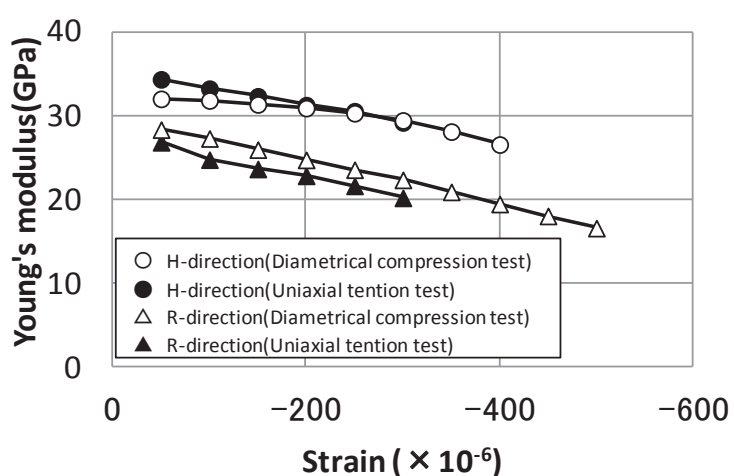

Fig.6 Secant Young's modulus of Inada granite.

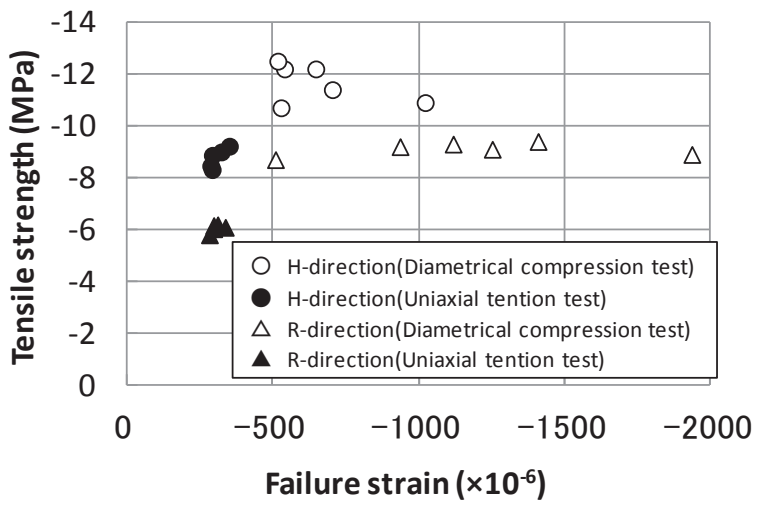

Fig.7 Relation between failure strain and tensile strength.

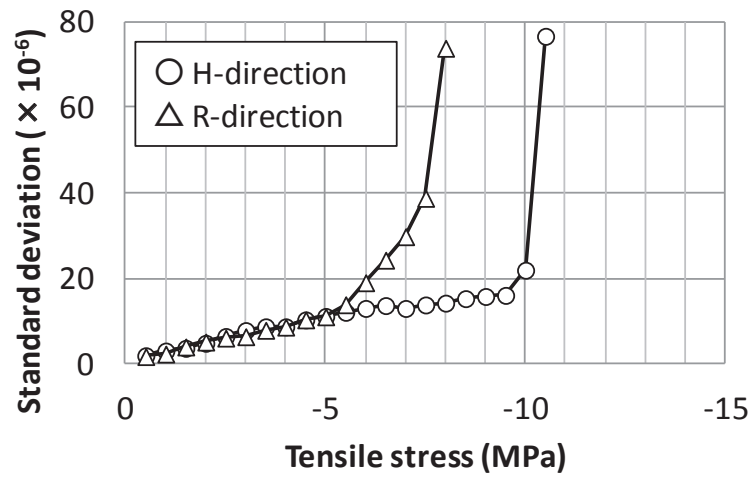

Fig.8 Relation between tensile stress and standard deviation of strain obtained by equation (11).

な方向に載荷した場合の軸ひずみ と割線ポアソン比 $v_{\mathrm{CH}}$ およびRift plane に平行な方向に載荷した場合の軸 ひずみ $\varepsilon$ と割線ポアソン比 $v_{\mathrm{CR}}$ との関係を Fig.5 に示す いずれの方向も割線ポアソン比の值は軸ひずみ $\varepsilon の 一$ 次関数で近似することができ，この值を（11）式に用い た。（11）式に用いるひずみゲージの計測值 $\varepsilon \times$ および $\varepsilon$ r は弾性ひずみと弾性ひずみ以外のひずみの合計值であ ると考えられる。このため、弾性変形以外の変形をも考 慮した割線ヤング率を求めることができると考えられ る. また, 圧裂試験時の割線ヤング率の異方性も考慮で きるものと考えられる.

（5）式によって求められる応力を（11）式によって 求められるひずみで除すことにより,引張応力下におけ

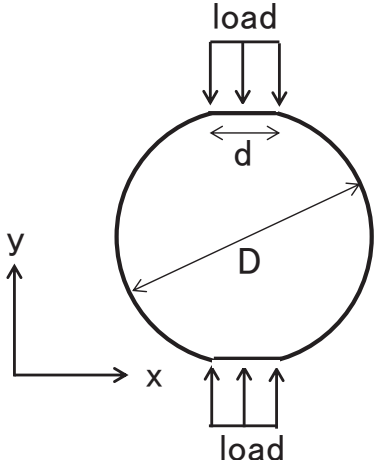

Fig.9 Schematic diagram of the test.

る割線ヤング率を求めた結果を Fig.6 に示す。図には, 一軸引張試験の結果 ${ }^{3)}$ も合わせて示した. H方向および R方向ともに，圧裂試験により求めたヤング率は，一軸 引張試験で求めたヤング率とほぼ等しい. また、H方向 とR方向で割線ヤング率が異なるという異方性も確認 できる.このことから, 本研究で示した方法により, 圧 裂試験結果から稲田花崗岩の引張応力下における割線 ヤング率を推定できるものと考える.

上述した方法では一軸圧縮試験の結果から得られる 割線ポアソン比を（11）式に使用する。ここでは（11） 式に用いる割線ポアソン比の值を一定の值とした場合 について考察する. Fig.5 に示したように稲田花崗岩の割 線ポアソン比はひずみレベルに依存する。割線ポアソン 比の值は $0.05 \sim 0.17$ と比較的小さな值を示す.これは, 一軸圧縮試験時のひずみレベルが小さい領域ではマイ クロクラックの閉塞による軸ひずみが大きいことが原 因であると考えられる。（11）式においてH方向および R方向ともに割線ポアソン比の值を 0.10 とし, 引張ひず みが一軸引張試験時 ${ }^{3)}$ の破壊ひずみとほぼ等しい-300 $10^{-6}$ における割線ヤング率の值を求めてみた. その結果, $\mathrm{H}$ 方向では 6 供試体の平均值で $29.5 \mathrm{GPa}, \mathrm{R}$ 方向では 21.5GPa であり, Fig.6 に示した值である 29.4GPa および $22.3 \mathrm{GPa}$ と大きな差は見られなかった。このことから，

(11) 式に用いるポアソン比の值を 0.10 と仮定すれば, 一軸圧縮試験の結果から求められる割線ポアソン比の 值を使用寸ることなく, 割線ヤング率の近似值を推定で きるものと考えられる.

\section{$4 \cdot 2$ 引張強度に関する考察}

圧裂引張破壊時に（1）式で求められる引張強度と（11） 式で求められる破壊時のひずみとの関係を Fig.7 に示す. 図には一軸引張試験 ${ }^{3)}$ の結果も合わせて示した. H方向 およびR方向ともに，圧裂試験で求められる破壊時のひ ずみおよび引張強度は，一軸引張試験に比べて大きいこ とがわかる．また，H方向およびR方向ともに，供試体 間でひずみのばらつきが一軸引張試験時に比べて極め て大きいことがわかる。（1）式で求められる応力が $0.5 \mathrm{MPa}$ ごとに，(11）式で求められるひずみの各方向 6 供試体の標準偏差を求めたものを Fig.8 に示す．標準偏 
差の值は応力の増加に伴い一定の勾配で増加していく が，H方向では-9.5MPa， R方向では-5.0MPa を超える と值が急激に増加することがわかる。ここではこれらに ついて考察する.

圧裂試験は Fig.3 に示したように供試体に線荷重が載 荷するものと仮定している。しかし, 荷重の増加に伴っ て載荷線付近には局所的な圧縮応力が発生して破壊を 生じ, Fig.9 に示すような載荷幅 $\mathrm{d}$ の面荷重の条件に変化 するものと考えられる. 尾田ら ${ }^{7)}$ は, 載荷幅 $\mathrm{d}$ を直径 $\mathrm{D}$ で除した值 $\mathrm{d} / \mathrm{D}=0.1$ の場合について, 圧裂引張面に生 じる $\mathrm{x}$ 方向の応力 $\sigma_{\mathrm{x}}$ と $\mathrm{y}$ 方向の応力 $\sigma_{\mathrm{y}}$ の分布につい て報告している。これによると, 供試体中心から直径の $60 \%$ 程度の範囲内では，。 定した場合の理論值と， $\mathrm{d} / \mathrm{D}=0.1$ の場合の值が一致す る。しかし, 荷重が作用する供試体上下のそれぞれ直径 の $20 \%$ 程度の範囲では， $\sigma_{\mathrm{x}}$ および $\sigma_{\mathrm{y}}$ ともに值が理論 值と異なり, 圧裂引張応力に相当する $\sigma$ x の值は端部に 近づくにつれて引張側の応力から圧縮側の応力になる ことを報告している.

圧裂試験中に荷重が増加して荷重が Fig.9 に示したよ うな面荷重に変化したかどうかについては, 直接計測す ることはできなかったが，ここでは以下のように載荷幅 $\mathrm{d}$ を直径 Dで除した值 $\mathrm{d} / \mathrm{D}$ を推定する. すなわち, 供試 体が上下加圧板に接する部分では， $\sigma_{\mathrm{y}}$ が供試体の一軸 圧縮強度 $\mathrm{S}_{\mathrm{C}}$ を超えることは考えにくい.このため， $\sigma_{\mathrm{y}}$ は $\mathrm{S}_{\mathrm{C}}$ に等しいと仮定する，この場合，（12）式が成り立 つ.

$$
\mathrm{S}_{\mathrm{C}}=\mathrm{P} / \mathrm{d} \mathrm{L}
$$

ここで，Pは荷重，Lは供試体長さである。（12）式 における荷重 P と（2）式における荷重 Pが等しい場合, (13）式の関係が成り立つ.

$$
\frac{\mathrm{d}}{\mathrm{D}}=-\frac{\pi}{2} \cdot \frac{\mathrm{S}_{\mathrm{T}}}{\mathrm{S}_{\mathrm{C}}}
$$

著者がこれまでに報告している稲田花崗岩の一軸圧 縮強度 $\mathrm{S}_{\mathrm{C}}$ はH方向で $190 \mathrm{MPa}, \mathrm{R}$ 方向で $209 \mathrm{MPa}$ である 10). 一方, 一軸引張強度 $\mathrm{S}_{\mathrm{T}}$ はH方向で-8.8MPa, R方向 で-6.1MPa である ${ }^{3)}$ 。これから- $\mathrm{S}_{\mathrm{T}} / \mathrm{S}_{\mathrm{C}}$ の最大值を計算 すると $8.8 / 190 \fallingdotseq 0.046$ となり，これを（13）式に代入す ると $\mathrm{d} / \mathrm{D} \fallingdotseq 0.072$ が得られる. 以上のことから, 圧裂試 験中に荷重が線荷重から面荷重に変化したとしても, d /Dの值は 0.1 以下であり, 尾田ら ${ }^{7)}$ が報告している条件 の範囲内と推察される.

今回の測定に使用したひずみゲージは，供試体中心に 貼り付けた。 ゲージ長は $10 \mathrm{~mm}$, 幅は $3 \mathrm{~mm}$ であり、そ れぞれ供試体直径の $29 \%$ および $9 \%$ に相当する. Fig.2 に示した $\varepsilon_{\mathrm{x}}$ および $\varepsilon_{\mathrm{y}}$ の測定範囲では, 圧裂引張破壊面
に生じている $\sigma_{\mathrm{x}}$ および $\sigma_{\mathrm{y}}$ は, 荷重が線荷重とした理論 值と等しい部分で計測しているものと考えられる。この 場合, 供試体中央部で $\sigma{ }_{\mathrm{x}}$ が引張強度に達したとしても, 上下加圧板の近傍では $\sigma_{\mathrm{x}}$ は引張強度に達しない場合が 考えられる. 寸なわち, 供試体中央部で引張破壊してい るものの, 供試体全体としては破断には至らない状態が 考えられる. Fig.8 ではH方向で-9.5MPa, R方向で -5.0MPa を超えるとひずみの標準偏差が急激に大きくな ることを述べた。これらの応力を超えると供試体中央部 は引張破壊をしているものの，供試体全体としては破断 に至らないため, ひずみの計測值に大きなばらつきを生 じたものと考えられる.

Table1 に示したとおり，供試体破断時の最大荷重から （1）式で求めた圧裂引張強度はH方向で-11.6MPa， R 方向で-9.1MPa であった。 これは一軸引張試験の結果 ${ }^{3)}$ であるH方向で-8.8MPa, R方向で-6.1 MPa に比較して明 らかに大きい. しかし, Fig.8に示したようにH方向では -9.5MPa，R方向では-5.0MPa を超えるとひずみの標準偏 差が大きくなり，この值は一軸引張強度と大きな差は見 られない. 以上のことから，（1）式によって最大荷重 により引張強度を評価すると, 引張強度を過大に評価し てしまう可能性があると考えられる.

\section{5 結言}

本研究では稲田花崗岩を用いて供試体にひずみゲー ジを貼り付けた状態で圧裂試験を行い, 圧裂破断面が $\mathrm{H}$ 方向およびR方向に一致する場合の圧裂引張強度を評 価した. また, ひずみの計測值から引張応力下における ヤング率を推定するとともに，引張強度に関する考察を 行った。本研究で得られた成果は以下のとおりである. 1 ）供試体に作用寸る荷重から（5）式によって得られ る圧裂引張破壊面に生じている応力を，（11）式で得ら れるひずみで除すことにより引張応力下におけるヤン グ率を推定した。 その結果，これまでに報告されている 一軸引張試験の結果と大きな差は見られなかった。この ことから, 本研究で示した方法で圧裂試験により岩石の 引張応力下におけるヤング率を推定できるものと考え られる。

2 ）（11）式で得られるひずみの標準偏差を計算した結 果, H方向では-9.5MPa，R方向では-5.0MPaを超えると 標準偏差が急激に大きくなる．この原因として，荷重が 大きくなることで線荷重が面荷重へと変化し, 圧裂引張 破壊面に生じる $\sigma_{\mathrm{x}}$ が供試体内で異なることが考えられ る.このことから，（1）式によって最大荷重により引 張強度を評価すると, 岩石の引張強度を過大に評価して しまう可能性があると考えられる.

\section{参考文献}

1) Y. Kudo, O. Sano and K. Furukawa and K. Nakagawa, "Tensile strength distribution of granitic rocks in diametrral compression test", Journal of the Japan Society of Civil Engineering, No.400, III-10, pp.233-241(1988).

2) S. Okubo, F. Jin and M. Akiyama, "Loading-rate 
dependency of uniaxtial and indirect tensile strength", Shigen-to-Sozai, Vol.109, pp.865-869(1993).

3) Y. Kohmura, "A study on anisotropy under tensile stress of inada granite", Journal of the Society of Materials Science, Japan (submitted)

4) W. Lin, M. Takahashi, Y. Fujii, S. Nishiyama and T. Takemura, "Deformability of several granitic rocks and gabbros in uniaxial tension", Journal of the Society of Materials Science, Japan, Vol.56, No.7, pp.654-659(2007).

5) Y. Hiramatsu, M. Nishihara and Y. Oka, "A discussion on the methods of tension test of rock", Nihon-kougyoukaishi, Vol.70, No.793, pp.285-289(1954).

6) Y. Hiramatsu, Y. Oka and H. Kiyama, "Investigation on the disc test, ring test and indentation test for rocks", Vol.85, No.969, pp.8-14(1969).

7) J. Oda and K. Yamasaki, "Zeiseizairyou-no-shin-atsuresu -shikenhou-nitsuite", Nihon-kikaigakkai-ronbunnshuu (dai-1-bu), Vol.44, No.378, ppp.478-488(1978).

8) A. Tsurusaki and J. Oda, "An evaluation method for the tensile strength of brittle materials by means of new indirect tension test", Nihon-kikaigakkai-ronbunnshuu (A-hen), Vol.50, No.453, pp.1062-1068(1984).

9) Y. Kohmura, "A study on critical strain of rocks", Journal of the Japan Society of Civil Engineering, C, Vol.68, No.3, pp.526-534(2012)

10) Y. Kohmura, "A fundamental study on stress-strain characterization of inada granite including post-failure region", Journal of the Society of Materials Science, Japan, Vol.61, No.3, pp.233-238(2012).

11) U. Yamaguchi and Y. Nishimatsu, "Ganseki-rikigaku -nyuumonn", Tokyo-daigaku-shuppannkai, pp.123-125(1987) 